Alenka TEMELJOTOV SALAJ

\title{
Sinergični učinek opazovalca grajenega okolja
}

\section{Okolje \\ Vrednotenje \\ Odnos do \\ nepremičnin \\ Environment \\ Evaluation \\ Relation to \\ real estate}

Izziv sodobnega časa ni vezan samo na hiter tempo življenja, veliko obveznosti in čim večjo učinkovitost $v$ delovnem procesu, ampak je tudi $v$ dojemanju grajenega in naravnega okolja $v$ vsakodnevnem ritmu. Kolikokrat smo se pri hitenju s sestanka na sestanek zalotili, da nas zmotijo težko dostopna lokacija, zasedenost parkirišč, slaba vzdrževanost prostorov, neurejena klimatizacija. Po drugi strani se nam pogled spočije na zelenih parkovnih nasadih, pretakanju vode, ugodno se počutimo $v$ lično urejenih prostorih. Vse to podzavestno in tudi zavestno opažamo, zaznavamo, si zapisujemo v spomin. Sinergični učinek tega odnosa človeka in okolja je bila tematika sociopsihološke raziskave, ki je predstavljena v nadaljevanju. Gre za odnos posameznika ali skupine do nepremičnin, in sicer glede na tehnične, socialne, psihosocialne, zgodovinske in ekonomske vplive. Ukvarja se z analizo odnosa med nepremičninskim statusom družine in klimo, samoevalvacijo članov, vrednotami, drugimi orientacijami, življenjskim slogom ter identiteto ali učinkovitostjo posameznikov.

\section{Odnos opazovalca in okolja}

Življenjski prostor se lahko deli na mikro- in makrookolje; mikrookolje je naša neposredna okolica, kjer živimo, delamo in preživljamo prosti čas. Značilnosti fizičnega mikrookolja, zlasti stanovanjskega in delovnega, lahko pomembno vplivajo na kakovost našega življenja (Rus, 1997). Fizikalno okolje naj bi bilo tisto, kar obstaja neodvisno od posega človekove roke, oblikovano okolje pa naj bi bilo rezultat takega posega. Številne komponente fizikalnega okolja so danes že posredna ali kar neposredna posledica človekovega posega v naravo (Rus, 1997).

Makrolokacijo objekta Kovičeva (1992) opredeljuje z makroklimo območja, geografsko širino in nadmorsko višino, ki so tisti faktor-
The challenge of modern times is not only tied to the fast pace of life, many responsibilities and high effectiveness in the working process, but also to perception of the built and natural environemnt in one's daily rythm. While rushing from one engagement to another, we often stop to complain and vent our dismay over difficult accesses, full parking lots, poorly maintained places, bad air-conditioning. On the other hand we rest when watching green park planting, the play of running water, we feel at ease in pleasantly decorated places. Concsiously or unconsciously all are observed, percieved and coded in our memories. The synergetic effect of this relationship between humans and the environment was the topic of the social-psychological research presented in this article. The issue is the relation of the individual or group to real estate from the aspects of social, psycho-social, historical and economic influences. It deals with the analysis of relations between the property status of families and climate, self-evaluation by members, values, other inclinations, lifestyle and identity or efficiency of individuals.

ji, ki določajo okvirno tipologijo arhitekturne oblike. Vendar opozarja, da umetno preoblikovana mesta porušijo ravnotežje naravne klime ter ustvarjajo t. i. urbano klimo, za katero je značilno povišanje temperature, in sicer zaradi večje akumulativnosti grajene mestne strukture, povečanega zajema vpada sončnega sevanja zaradi večkratne refleksije in absorpcije, oviranega nočnega oddajanja sevalne toplote, povečane refleksije, bližine objektov in odboja toplote od plasti smoga nad mestom, oslabljene in poškodovane vegetacije, prehitrega odvajanja deževnice, manjkajoče vodne površine, brezvetrja in mirujoče plasti nad mestom ter nenehnega dodatnega ogrevanja zaradi toplote, ki jo ob svojem obratovanju sproža mesto.

Mesto je prostor, v katerega so nerazdružljivo povezane tri temeljne sestavine okolja: naravno, ki daje bazo z obliko zemljišča, njegovo 
strukturo in lastnostmi, $\mathrm{z}$ vodo, vegetacijo, favno in klimo; družbena naselitev, ki vključuje tako posameznika kot skupnost, aktivnosti, institucije, kulturo s šegami in navadami; materialni produkti, ki oblikujejo kulturo družbe $z$ objekti, napravami in sredstvi. Vse tri skupaj izražajo celovitost dogajanja in sodelovanja narave, bitij ter stvari v dinamičnem procesu sprememb in obnavljanja, iz katerega ni izključena niti preteklost niti $\mathrm{v}$ razvoj obrnjena prihodnost. Umetno okolje, ki je postalo dominantno bivalno okolje, ustvarja pri človeku v času industrijske, potrošniške miselnosti veliko praznino, občutenje socialnih razlik, pomanjkanje občutenja skupnosti, krajinske identitete ter duhovnih dimenzij v življenju (Siregar, 2002).

$\mathrm{Na}$ socialno vedenje $\mathrm{v}$ nekem bivalnem prostoru vplivajo fizikalne značilnosti, kot so njegova velikost, razpored prostorov, zvočnost, barve, starost, višina, razgled, stran neba, dostop do prometnih zvez, trgovin in drugih storitvenih dejavnosti, velikost, razpored in oblika pohištva, ogrevanje, vlažnost zraka in prostorov, opremljenost s komunikacijsko tehnologijo, namembnost prostorov, status soseske ...

Kot pravi Trstenjak (1987), je vidni doživljaj dinamičen. Kar človek opaža, niso samo barve, oblike, gibanje in velikost predmetov, ne zaznava samo vidnega predmeta, temveč tudi sebe kot gledajočega, čeprav je ravno $\mathrm{v}$ vidnem čutu predmetna usmerjenost najbolj razvita. V gledanju je obrnjen $\mathrm{k}$ svetu $\mathrm{v}$ pričakovanju: zaznava je odvisna od kraja opazovanja, načina gibanja, časa in trajanja, obsega in oblike predinformacij. Urbano zaznavo je možno členiti po poteku premišljenega ravnanja, dostopnosti informacij in vrstnemu redu zaznave. Zaznava prispeva le neznaten del predmetne stvarnosti in spomin le del preteklosti, toda domišljija podatke razširja in razlaga sliko sveta.

Psihološke študije okolja se ukvarjajo tudi $\mathrm{z}$ interakcijo med posameznikom in fizikalnim okoljem oz. s posameznimi komponentami tega okolja. Pri tem je mišljeno medsebojno delovanje oz. vpliv okolja na posameznika in obratno. Piaget (1965) je predstavil interaktivni odnos s procesoma asimilacije (prilagajanje nečesa sebi) in akomodacije (prilagajanje sebe okolju). Socializacija kot socialna implikacija interakcije med posameznikom in fizičnim okoljem je rezultat dejavnikov fi- zikalnega okolja, socialnega okolja in posameznika samega. Socializacijski procesi so tako procesi socialnega vplivanja kot procesi socialnega učenja (Rus, 1997).

\subsection{Modeli za raziskovanje odnosa opazovalca in okolja}

Temeljna vprašanja v študijah okolja so, kako so različna okolja povezana s socialnim vedenjem, kakšne so interakcije med okoljem in socialnim vedenjem, kakšno je njuno prilagajanje spremembam, ki jih sprožata. Modeli interakcije med človekom in okoljem se nanašajo na analizo socialnih spremenljivk (posameznik in skupina, osebnost, kultura, vloge, organizacije, socialnoekonomske značilnosti) ob upoštevanju vpliva fizikalnih dejavnikov ter analizo spremenljivk fizikalnega in oblikovanega okolja (arhitekturne in pokrajinske značilnosti, značilnosti procesov v okolje, obseg in pogostnost različnih dogodkov v okolju).

Poznamo kognitivne in odločitvene modele interakcije med človekom in okoljem. Kognitivni se ukvarjajo predvsem z vprašanji, kot so odnos med značilnostmi okolja in osebnostnimi značilnostmi, kako se razlike v kognitivni percepciji in kategorizaciji (fizikalnega) okolja kažejo pri različnih socialnih in kulturnih skupinah in v njihovem socialnem in prostorskem vedenju (fizična razdalja v medosebni komunikaciji npr.), stališča do fizikalnega okolja in stereotipi, kakšne so socialne reprezentacije različnih makroobjektov in makrodogodkov.

Funkcija kognitivnih modelov okolja je v zmanjševanju njegove kompleksnosti. Kategorizacija okolja kot izraz kognitivnega modela interakcije med človekom in okoljem ima splošne značilnosti, kot so:

- redukcija kompleksnosti, večja razumljivost in predvidljivost,

- psihodinamična funkcija, ki se kaže v zadovoljitvi potrebe po varnosti - varnejši se počutimo v okolju, ki ga razumemo in zmoremo predvidevati dogodke $\mathrm{v}$ njem.

Odločitveni model interakcije med človekom in okoljem pa se nanaša na »izbor v negotovem « (Rus, 1997). Glavna vprašanja odločitvenega modela so naslednja:

- kako se presojajo koristnosti različnih možnosti, 
- kako se sprejemajo odločitve v zvezi z različnimi predvidljivimi in nepredvidljivimi dogodki fizikalnega okolja,

- kako strokovnjaki v primerjavi z drugimi strokovnjaki ocenjujejo tveganja pri sprejemanju odločitev o različnih razvojnih prioritetah,

- pri teh vprašanjih gre za aplikacijo že uporabljenih modelov in rešitev na konkretnem problemskem področju.

Vedenje v prostoru je ena od značilnosti neverbalne komunikacije: proksimalna komunikacija je tista neverbalna komunikacija, ki se nanaša na prostorske značilnosti neverbalnega vedenja - ena izmed njih je fizična razdalja med komunikatorji. Osebni prostor je individualni teritorij, ki je hkrati nekakšna zaščita njegove osebne integritete (Rus, 1997). Teritorialnost kot način vedenja na določenem teritoriju in socialna interakcija sta povezani spremenljivki, na obe pa vplivajo značilnosti okolja. Fizična bližina naj bi olajševala, v določenih primerih spodbujala socialno interakcijo, zveze med fizično in psihološko distanco pa niso enoznačne. Včasih je ravno premajhna distanca tista, ki spodbudi psihološko in socialno distanco. Včasih se celo zgodi, da psihološka in socialna distanca delujeta kot obrambni mehanizem pred preveliko bližino tam, kjer fizična postaja celo moteča.

\section{Vrednost za opazovalca}

Menjava na trgu je povezana s konceptom vrednosti in vrednot. Na vrednost lahko gledamo kot na ekonomsko kategorijo, na vrednoto pa kot na psihološko. Cena je npr. v denarju izražena vrednost, vrednote pa psihološko obravnavamo kot preferenčni koncept želenega. Tako ekonomski koncept vrednosti kot psihološki koncept vrednot sta tesno povezana.

Vrednota je po Rokeachu (1960) trajno prepričanje, specifična oblika vedenja ali končnega stanja eksistence, osebno ali družbeno bolj zaželena od nasprotne oblike vedenja oz. končnega stanja eksistence. S tem definira tudi pojem vrednostnega sistema. Ta je relativno trajna organizacija in struktura prepričanj, ki se na kontinuumu relativne pomembnosti nanaša na osebno in socialno bolj zaželene oblike vedenja in končnega stanja eksistence.

\subsection{Vrednotenje nepremičnine}

Načela vrednotenja nepremičnin so razvrščena na subjektivne in objektivne, med seboj prepletene kategorije: načela, ki temeljijo na percepcijah uporabnikov, načela, ki so povezana s tržnim okoljem. Nepremičnini lahko v vsakem trenutku njenega življenjskega ciklusa, od načrtovanja, njenega »rojstva«, rasti, sanacije, propadanja in »smrti «, določimo njeno vrednost. Zemljišče s svojo umeščenostjo namreč narekuje izkoristljivost. S pozicijo znotraj urbanega ali neurbanega območja nam določa primarno vizijo njene bodoče rabe. Od trenutka, ko je zemljišče umeščeno kot vodilni element v krog miselnega procesa s svojo pozicijo znotraj civilizacijskega zemljevida $\mathrm{z}$ njenimi prometnimi smermi, infrastrukturnimi ureditvami in ostalim okoljem, se začne proces planiranja od ideje do realizacije. Načrtovanje in razvoj sta pri tem pomembna elementa. Enako tudi minuli, sedanji in bodoči razvoj celotnega mikro- in makrookolja.

Pri opazovanju okolice in ustvarjanju mnenja o njej lahko omenim stališča, to je odnos, ki ga ima posameznik do nekoga ali nečesa. Stališča se lahko prikažejo kot odnos, ki ima tri značilnosti: kognitivno, čustveno oz. ocenjevalno in pripravljenost za vedenje. Allport (1954) jih je definiral kot stanje mentalne pripravljenosti, organizirane kot izkušnja, ki neposredno vpliva na posameznikove odgovore $\mathrm{v}$ zvezi $\mathrm{z}$ objekti in situacijami, do katerih ima določen odnos. Stališča so tesno povezana $\mathrm{z}$ osebnimi vrednotami.

$\mathrm{Na}$ nepremičninskem trgu se bolj kot kje drugje poudari instrumentalni vidik zadovoljevanja potreb in akcijske usmerjenosti $\mathrm{k}$ nepremičninskemu cilju. Zato se socialno-psihološka teorija socialne interakcije v okviru pojma trg ukvarja tudi z instrumentalnimi vidiki skupinskega in posameznikovega vedenja. Instrumentalnega vidika ne more mehanično izločiti iz konstrukta, ki se imenuje motivacijski ciklus. Instrumentalni vidik je namreč tisti, ki močno določa posameznikov način zadovoljevanja potreb (Rus, 1997). Tako določa tudi njegov (socialni, ekonomski, kulturni) status pa tudi odnos do samega sebe. Socialne (tržne) interakcije ni brez igralcev (socialno-ekonomskih) vlog (povpraševalcev in ponudnikov). Vloge in pripadajoči statusi so izraz strukturalnih značilnosti skupine oz. situacije. Teorija, ki se ukvarja s tržno (socialno) interakcijo, vlog ne more ize- 
načiti s statusom (kjer je oboje definirano samo kot pričakovanje). Na razvitem trgu so vzorci vedenja, ki se pričakujejo od povpraševalca in ponudnika, jasno definirani oz. ciljno usmerjeni. Na razvitem trgu so definirani s številnimi (formalnimi) pravili, normami, predpisi in celo procedurami (ki težijo $\mathrm{k}$ temu, da so ekonomični in racionalni). Na analizi principa menjave (equity change in equality change) temeljijo tudi sodobne teorije socialne izmenjave, kar je samo drugačen izraz za vprašanja socialne pravičnosti.

S socialno-psihološkega vidika se pripravljenost za nakup oz. prodajo obravnava v sklopu kategorije stališč: $v$ trikomponentnem modelu stališč pripravljenost $\mathrm{za}$ določeno vedenje (prodajo ali nakup) pomeni tretjo komponento stališč. Pripravljenost za nakup je poleg tega tista faza $v$ modelu potrošnikovega vedenja, ki je pred akcijo (nakupom). Potencialni potrošnik mora biti na dobrino ali storitev najprej pozoren, pozornost mora $\mathrm{v}$ njem vzbuditi interes, ko se za nakup odloči, ga mora tudi uresničiti. Pripravljenost je izraz stopnje odločenosti ali prepričanosti o nakupu. Tisti, ki se je že odločil, se lahko tudi premisli. Verjetnost spreminjanja odločitve je obratno sorazmerna prepričanosti oz. pripravljenosti, da se jo uresniči. Pripravljenost za nakup pa postane realna ekonomska oz. tržna kategorija tedaj, ko je plačilno zmožna. Motiv realizacije pripravljenosti za nakupovanje oz. individualnega odločanja za nakup (attention/ interes/ desirel action) je percepcija razlike med koristnostjo blaga in koristnostjo denarja. Večja ko je ta razlika v korist blaga, močnejši bo omenjeni ekonomski motiv. Percipiran presežek koristnosti blaga nad koristnostjo denarja se imenuje potrošnikov dobiček. Tudi ta kategorija je torej ekonomsko-psihološka. Samo trženje nepremičnin je proces, ob pomoči katerega posamezniki in skupine zadovoljujejo svoje potrebe in želje in v katerem se nepremičnine ter $\mathrm{z}$ njimi povezane storitve ustvarjajo, ponujajo in medsebojno izmenjujejo (Falk, 1997).

\section{Zaznava grajenega okolja}

V nadaljevanju je predstavljenih nekaj rezultatov, ki so nastali pri raziskavi problematike nepremičnin $\mathrm{v}$ povezavi s problematiko fizičnega in socialnega okolja. Uporabljen je bil dvodelni vprašalnik, katerega avtor je Velko S. Rus s sodelavci. Prvi del je zajel osnovne demografske podatke ter podatke o nepremičninah, v drugem delu so bila vprašanja o zaznavi uresničenosti posamičnih vrednot, zadovoljenosti lastnih psihosocialnih potreb, ocene lastnega življenjskega stila, psihosocialnih blokad podjetništva ... Raziskava je bila zelo široko izvedena, predstavljeni so le trije rezultati za primere bivalnega prostora, delovnega prostora ter urbanega in socialnega prostora bivanja.

$\mathrm{V}$ raziskavi so bile anketirane tri skupine udeležencev:

1. lastniki oz. zaposleni v zasebnih nepremičninskih agencijah v Republiki Sloveniji ( $\mathrm{n}=31$, s povprečno starostjo 43 let in $\mathrm{z}$ deležem 0.6 moških udeležencev »nepremičninarji $\ll)$;

2. skupina Slovenk oz. Slovencev, zaposlenih na vplivnih delovnih mestih, relativno javno znani in pričakovano javnomnenjsko vplivni $(\mathrm{n}=24$, s povprečno starostjo 39 let in deležem 0.6 ženskih udeleženk »drugi $\ll$ );

3. skupina zaposlenih strokovnjakov (gradbeništvo in arhitektura) iz Maribora ( $\mathrm{n}=$ 28, s povprečno starostjo 37 let, $\mathrm{z}$ deležem 0.43 moških udeležencev - »strokovnjaki « - anketiranje je izvedla Tina Škrinjar iz Maribora).

Prikazana skupina rezultatov zasleduje različne vidike zastavljenih problemov - pomen socialnih in vrednotnih orientacij, zaznav Življenjskega stila, nacionalnih stereotipov, ki jih imajo pri nastanku, ohranjanju in spreminjanju socialnih percepcij v zvezi s prostorom, okoljem in nepremičninami.

\subsection{Primerjava rezultatov idealnega / neidealnega bivalnega prostora (Slika 1)}

Iz slike je razvidno, da je percepcija idealnega bivalnega prostora povezana $z$ značilnostmi: a) da je $v$ hiši, zasebni lasti, obložen $z$ lesom, istočasno pa da ne bi bil ob mestnih vpadnicah; b) da bi bil v mestu, na nižjih nadstropjih, da bi bil sodobno zasnovan iz sodobnih materialov ter imel velika okna.

Kot pravi Pogačnik (1986), so sanje prebivalcev bogatejših držav prebivati v enodružinski hiši v čistem zelenem okolju blizu mesta, kamor se voziš na delo. Danes se urbanistično-arhitekturno snujejo mešana na- 


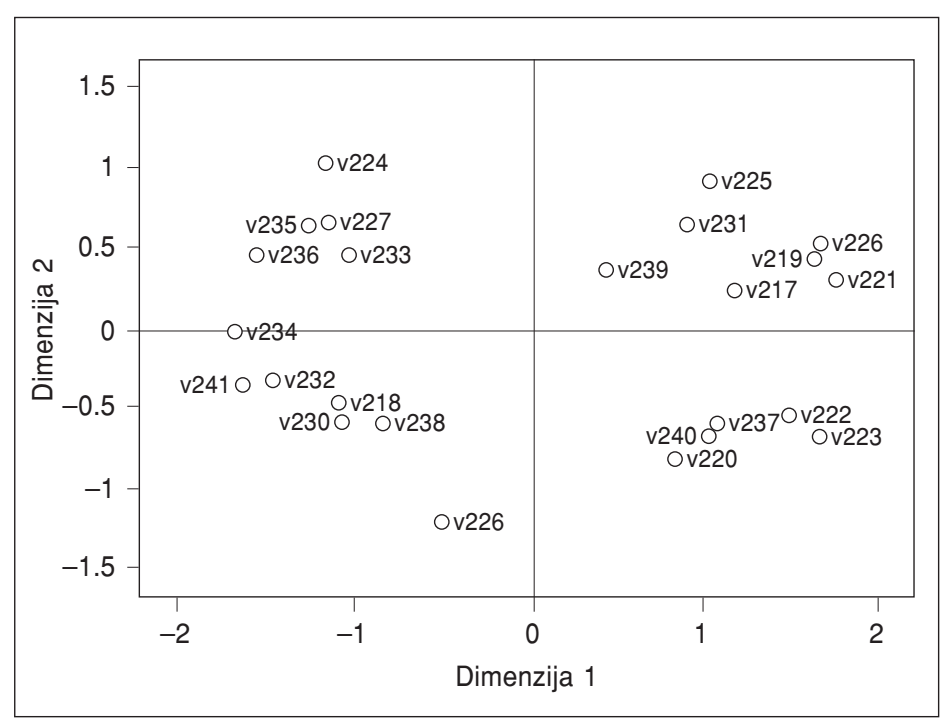

Slika 1: Evklidski distančni model idealnega oz. neidealnega bivalnega prostora

Opomba: IDEALNI PROSTOR: v217 - na nižjih nadstropjih, v218 - na višjih nadstropjih, v219 - zgrajena iz sodobnih materialov, v220 - obložen z lesom, v221 - z velikimi okni, v222 - v zasebni lasti, v223 - v hiši, v224 - v poslovni zgradbi, v225 - v mestu, v226 - na vasi, v227- ob mestnih vpadnicah, v228 - arhitekturno sodobno zasnovano, NEIDEALNI PROSTOR: v230 - na nižjih nadstropjih, v231 - na višjih nadstropjih, v232 - iz sodobnih materialov, v233 - obložen z lesom, v234 - z velikimi okni, v235 - v zasebni lasti, v236 - v hiši, v237 - v poslovnih objektih, v238 - v mestu, v239 - na vasi, v240 - ob mestnih vpadnicah, v241 - $\mathrm{s}$ sodobno zasnovo.

Numerus $=48$, Stress $=0.12, \mathrm{RSQ}=0.94$

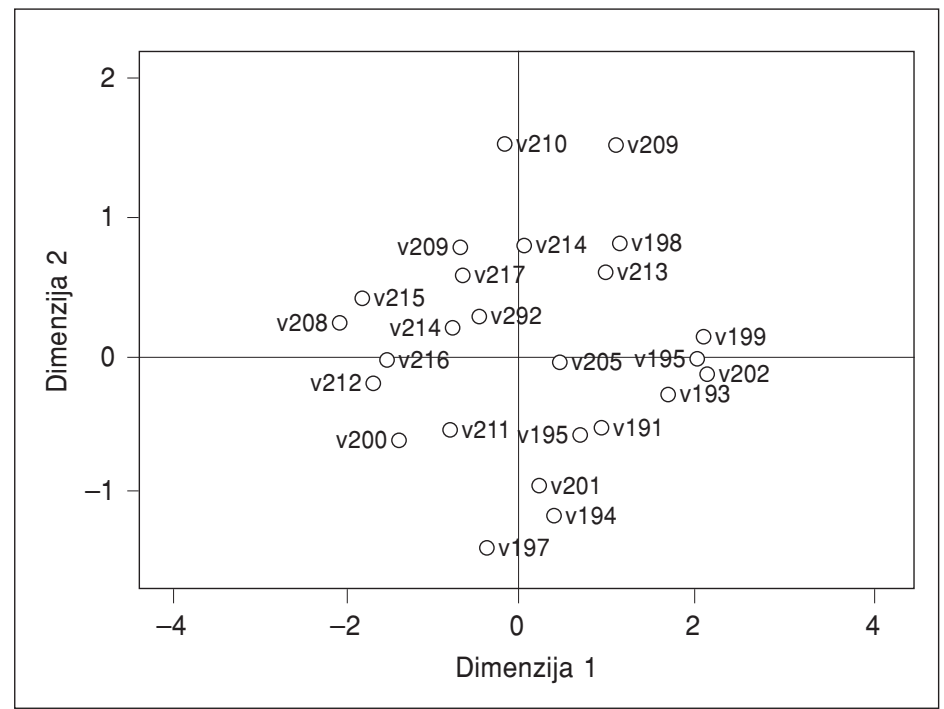

Slika 2: Evklidski distančni model idealnega oz. neidealnega prostora

Opomba: IDEALNI PROSTOR: v191 - na nižjih nadstropjih, v192 - na višjih nadstropjih, v193 - zgrajena iz sodobnih materialov, v194 - obložen z lesom, v195 - velika steklena okna, v196 - zasebna last, v197 - v hiši last, v198 - v poslovnih zgradbah, v199 - v mestu, v200 - na vasi, v 201 - ob mestnih vpadnicah, v202 - arhitekturno sodobno zasnovano, NEIDEALNI PROSTOR: v204 - na nižjih nadstropjih, v205 - na višjih nadstropjih, v206 zgrajena iz sodobnih materialov, v207 - obložen z lesom, v208 - velika okna, v209 - zasebna last, v210 - v hiši, v211 - v poslovnih zgradbah, v212 - v mestu, v213 - na vasi, v 214 - ob mestnih vpadnicah, v215 - arhitekturno sodobno zasnovano.

Numerus $=50$, Stress $=0.16, \mathrm{RSQ}=0.87$. selja blokovnih gradenj z umeščenimi individualnimi hišami, hišami v vrsti, zgradbe $\mathrm{s}$ hišami na strehah.

Potrebo po zasebni lastnini je obdelala Dominigue Lassare (1986) v raziskavi z naslovom Imeti hišo oz. nepremičninsko lastnino ali jo najeti. Pokazala je različen odnos do nepremičnine, odvisno od lastniškega statusa anketiranca - lastniki so ekonomsko in psihološko mnogo bolj vlagali v domove kot najemniki. Da bi zmogli visoke stroške, so manjšali izdatke za prostočasne dejavnosti, pri tem pa pojmovali svoj dom z okolico kot primarno prostočasno dejavnost. Izbran življenjski stil je sledil vzorcu sprejete odločitve o svojem domu. Dom so tudi veliko previdneje zbrali kot najemniki. Prehajanje iz najemniškega odnosa v lastniškega je bil le korak k doseganju želenega cilja - zgraditi svojo samostoječo hišo.

\subsection{Primerjava rezultatov idealnega /} neidealnega delovnega prostora (Slika 2)

Videti je, da se pojavljata dva principa zaželenosti delovnih prostorov - $\mathrm{v}$ urbanem prostoru, sodobno oblikovanih zgradbah, z velikimi okni, po drugi strani pa tudi nasprotje - na vasi ali v bližini mestnih vpadnic, obložen z lesom, v zasebni lasti, na nižjih nadstropjih.

Različna umeščenost delovnih prostorov je odvisna tudi od dejavnosti, s katero se posamezniki ukvarjajo, v urbanem okolju npr. je manj zelenih površin, večja utesnjenost urbanih enot, večja konfuznost parkirnih prostorov, prometnega režima.

Visoke stavbe so simbol socialne, ekonomske moči, prestiža ter državnega napredka (Barnard, Correa in Moser, 1987), po drugi strani pa Chuen (1996) pravi, da zgraditev visoke stolpnice pomeni zapiranje pogleda, odrezan tok sončne svetlobe in zraka ter tako znižanje bivalne vrednosti v njej. Komunikacija $\mathrm{z}$ ostalimi podjetji, zavodi, servisnimi službami, institucijami je v takem okolju preprostejša. Pri delovnem ritmu sodobnega človeka je optimizacija časa, ki ga delovni človek porabi za posamezna opravila, zelo pomembna.

V raziskavi o uporabnosti zdravstvenih objektov (Jenso in Haugen, 2005) je bila v ospred- 
ju uporabnost objektov z različnih percepcij opazovalcev: pacientov, zaposlenih in različnih strokovnjakov s področja gradnje medicinskih objektov. Zajeta je bila raziskava različnih stališč do posameznih elementov človeških in materialnih virov med procesom dizajniranja, gradnje ter uporabe objekta. S stališča uporabnikov so se kot trije najpomembnejši faktorji izkazali: učinkovitost, zmogljivost in zadovoljstvo.

\section{Primerjava rezultatov - mnenje o kraju bivanja in ljudeh, ki živijo v kraju bivanja (Slika 3)}

Če pogledamo najbolj strnjene rezultate, vidimo. da so najbolj povezane lastnosti kraja: čist oz. onesnažen, zabaven oz. dolgočasen, družaben oz. nedružaben, odprt oz. zaprt, v razcvetu oz. razsulu, z dobrim oz. slabim vodstvom, z dobro oz. slabo ponudbo; z naslednjimi lastnostmi ljudi, ki živijo v kraju bivanja: optimistični oz. pesimistični, zanimivi oz. enolični, živijo v skladu s seboj oz. v neskladju, preudarni oz. nepreudarni, prepričani oz. neprepričani o vrednosti lastnih ciljev.

V raziskavi, ki jo je predstavil Chris Heywood (2005), so se preverjale percepcije in pričakovanja opazovalca okolja na primeru knjižnice. Bistvo je, da je treba pričakovanja in percepcije uporabnika ovrednotiti tako s subjektivnega, objektivnega kot tudi psihološkega vidika. Pravi, da sta merjenje in vrednotenje uporabnikovih pričakovanj pomemben korak k uspešnemu in učinkovitemu managementu. Investitorji, urbanisti, arhitekti bi morali poleg objektivnih vrednostnih kazalcev pri gradnji objektov in okolja upoštevati tudi subjektivne in psihološke kazalce.

\section{Sklep}

V Sloveniji je to prva raziskava, ki zajema problematiko nepremičnin $\mathrm{v}$ povezavi $\mathrm{z}$ zaznavo socialne klime in kazalci učinkovitosti. Problematika nepremičnin je neločljivo povezana s problematiko fizičnega in socialnega okolja, ekologije, ekonomije, sociologije, prava, prometa, zdravstva, gradbeništva, urbanizma in arhitekture ter s sociopsihološkimi aspekti, ki so povezani z različnimi značilnostmi nepremičnin.

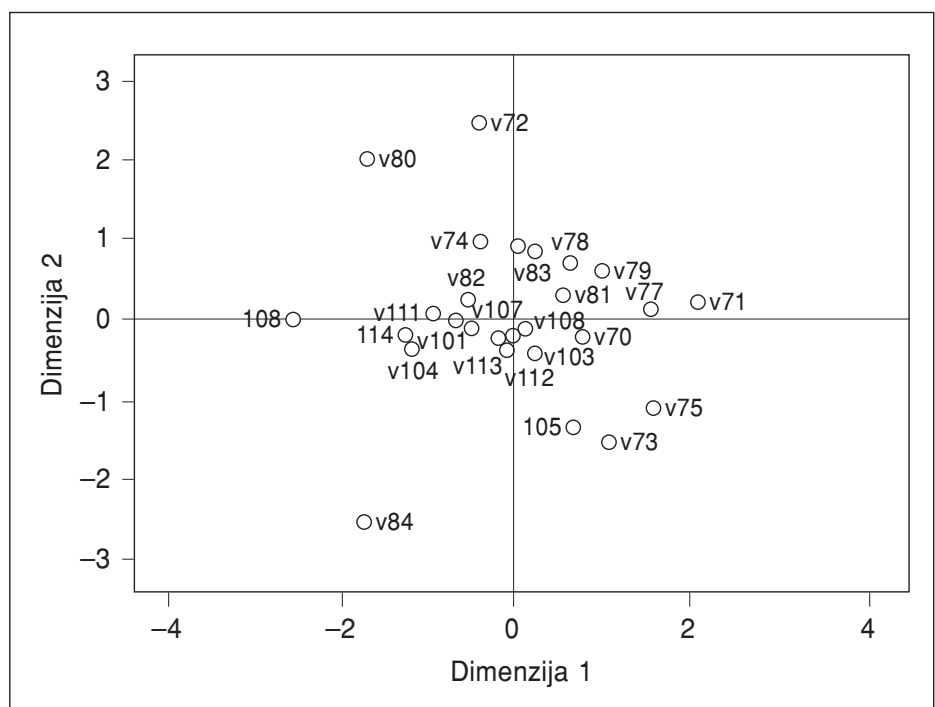

Slika 3: Evklidski distančni model mnenj o kraju bivanja in ljudeh, ki v kraju živijo.

Opomba: KRAJ BIVANJA: v70 - čist oz. onesnažen, v71 - preskrbljen oz. nepreskrbljen, v72 - kulturno zanimiv oz. nezanimiv, v73 - tih oz. hrupen, v74 zabaven oz. dolgočasen, v75 - miroljuben oz. poln nasilja, v76 - prijateljski oz. sovražen, v77 - prijazen oz. neprijazen, v78 - družaben oz. nedružaben, v79 - odprt oz. zaprt, v80 - živi s turizmom oz. ne, v81 - v razcvetu oz. razsulu, v82 - z dobrim oz. slabim vodstvom, v83 - z dobro oz. slabo ponudbo, v84 - dinamičen oz. tog, v85 - sodeluje oz. ne sodeluje z domačini, LJUDJE, KI ŽIVIJO V KRAJU BIVANJA: v101 - optimistični oz. pesimistični, v102 - aktivni oz. pasivni, v103 - neodvisni oz. odvisni od drugih, v 104 - vredni oz. nevredni posnemanja, v105 - umirjeni oz. vznemirljivi, v106 - orientirani na prihodnost oz. preteklost, v107 - zanimivi oz. enolični, v108 - usmerjeni na vsakdanje oz. nevsakdanje, v109 - v skladu s seboj oz. v neskladju, v110 uspešni oz. neuspešni, v111 - odprti oz. zaprti, v112 - preudarni oz. nepreudarni, v113 - prepričani oz. neprepričani o vrednosti lastnih ciljev, v114 - usmerjeni navznoter oz. navzven.

Numerus $=84$, Stress $=0.17, \mathrm{RSQ}=0.88$

Vsako od okolij, ki obkroža človeka, ima posebnosti, značilnosti, na katere smo lahko posebno pozorni, in sicer zato, ker so pomembne za človeka, njegovo življenje, preživetje, bivanje, prosti čas in delo. Vse te usmerjene pozornosti opazovalca se lahko ovrednotijo tako v smislu zadovoljitve želja in potreb kot tudi z ekonomski kazalci, kar pa je predmet nadaljevanja te raziskave.

Izvedena raziskava opozarja na interdisciplinarnost nepremičninskega področja, kjer se je treba lotiti reševanja nepremičninske problematike tudi s sociopsihološkega vidika, kjer se prepletajo niti želja, zavedanja, hotenja s produkcijsko-tehničnimi nitmi vsakdanjika.

Dr. Alenka Temeljotov Salaj, univ. dipl. inž. grad., Republika Slovenija, Ministrstvo za okolje in prostor, Ljubljana

E-pošta: alenka.temeljotov-salaj@gov.si 


\section{Viri in literatura}

Allport, G. W. (1954) The nature of prejudice, Addison Weslwey, Cambridge.

Barnard, P. R., Correa, C. M. in Moser, M. M. (1978)

Philosophy of tall buildings, American Society of Civil Engineers, New York.

Chuen, L. K. (1996) Tehnika prijetnega bivanja Feng Shui, Vale-Novak, Ljubljana.

Falk, P. (1997) The shopping experience, Thousand Oaks, London.

Heywood, C., Missingham, G., Kenley, R. (2005) Bridging the gap: Exploring expectations and perceptionsbased performance assessments, Facilities Business and its Management. Helsinki: Technical Research Centre of Finland, str. 267-279.

Jenso, M. in Haugen, T. (2005) Usability of Hospital Building - Is Patient focus Leading to Usability in Hospital Buildings? Facilities Business and its Management. Helsinki: Technical Research Centre of Finland, str. 347-361.

Kovič, S. (1992) Model energetske revitalizacije večnadstropne stanovanjske zgradbe: magistrska naloga, Univerza v Ljubljani, Fakulteta za gradbeništvo in geodezijo, Ljubljana.

Piaget, J. (1965) Etudes sociologiques, Librairie, Geneve.

Pogačnik, A. (2000) Mednarodna izhodišča in prostorski razvoj Slovenije, Urbani izziv, I. 11. št. 2, Ljubljana, str. 83-90.

Rokeach, M. (1960) Open and close mind, Basic Books, New York.

Rus, V. S. (1997) Socialna psihologija: teorija, empirija eksperiment, uporaba, Davean, Ljubljana.

Siregar, L. G. (2002) Ethical and ecological realization facing the globalization contribution from the vernacular architecture, 17. Conferences of the International Association for People-Environments Studies, Madrid, str. 87-88.

Trstenjak, A. (1987) Teorija zaznav, Slovenska akademija znanosti in umetnosti, Ljubljana. 